MUZIKOLOŠKI ZBORNIK - MUSICOLOGICAL ANNUAL IV, LJUBLJANA 1968

\title{
NEZNANI GALLUSOV AUTOGRAF?
}

\author{
Werner Bra u (Kiel)
}

Kot skoro za vse pomembne skladatelje 16. stoletja velja tudi za dela Jakoba Gallusa, da so ohranjena v dobrih tiskih iz tistega časa. To daje njegovi skladateljski zapuščini značaj močne avtentičnosti in olajšuje raziskovalcu in redaktorju stare glasbe delo. Po objavi zbirke »Opus musicum ( in maš $v$ »Denkmäler der Tonkunst in Oesterreich ( (1899$1935)^{1}$ in po preučevanju zbirke »Moralia ${ }^{2}{ }^{2}$ ter ponatisu enajstih kompozicij iz te ${ }^{3}$ je ustvarjalnost »Carniolusa ( dobro pregledna. $S$ to ugotovitvijo pa močno nasprotuje redkost biografskih dokumentov. Sicer je raziskovanje Gallusa zlasti v Jugoslaviji v zadnjem času veliko prispevalo $\mathrm{k}$ osvetlitvi njegove življenjske poti ${ }^{4}$ vendar manjka še vedno na primer neoporečno overovljen autograf tega glasbenika. ${ }^{5}$ To nas $\mathrm{v}$ toliko preseneča, ker so že v 16. stoletju prišle kompozicije direktno od avtorja $\mathrm{k}$ morebitnim interesentom. Tudi Gallus je vedel, na koga se je obračal. Svoje tiske je pošiljal prijateljem in mecenom ${ }^{6}$ in njegove osebne zveze so segale daleč v osrednjo Nemčijo.

Kdor se ukvarja $\mathrm{z}$ glasbeno zgodovino tega področja, naleti vedno znova na sledove Gallusa. Tu je imelo njegovo delo naravnost kanonsko veljavo; bil je »ljubljenec saških kantorij«. ${ }^{7}$ Skoro ni glasbenega inventarja iz konca 16. in iz 17. stoletja, ki ne omenja partov njegovih kompozicij in marsikatera zbirka rokopisov na Saškem navaja najpogosteje

1 Opus musicum, 6 delov, izdala E. Bezecny in J. Mantuani v DTÖ VI, 1, XII, 1; XV, 1; XX, 1; XXIV; Sechs Messen, izdal A. Pisk, istotam XLII, 1.

${ }^{2}$ H. W. Lanzke, Die weltlichen Chorgesänge von J.Gallus, disertacija Mainz 1963; prim. Die Musikforschung XVIII, 1965, str. 323. $3-60$.

3 Skladatelji Gallus, Plautzius, Dolar, izdal D. Cvetko, Ljubljana 1963, str.

4 Prim. D. Cvetko, J. Gallus à Olomuc et à Prague, Sborník praci filosofické fakulty Brněnske university XIV, 1965, str. 59-69 in druga dela tega avtorja.

5 Prim. sliko na str. 201 v Cretkovi knjigi Jacobus Gallus Carniolus, Ljubljana 1965. Ta kaže drugačne poteze kot vir, ki ga preučujem v svojem spisu. Za prijazna pojasnila se zahvaljujem dr. Martineku iz Prage.

${ }_{6} \mathrm{Na}$ primer opatu Janezu III Spindlerju v Kremsmünstru: A. Kellner, Musikgeschichte des Stiftes Kremsmünster, Kassel 1965, str. 150. Prim. tudi J. Mantuani v DTÖ VI, 1, XVIII in XXV.

7 H. Kretzschmar v Grenzboten, 1895, str. 23. 
njegovo ime. ${ }^{8}$ Nekatere kompozicije so bile posebno cenjene in spadale so $\mathrm{k}$ osrednjenemškemu standardnemu repertoarju; tako homofoni osemglasni zbor $) L a u s$ et perennins gloria $\star^{9}$ in seveda skoro večno znameniti žalni štiriglasni spev »Ecce quomodo moritur justus«.$^{10}$ Drugo zelo razširjeno delo, petglasni motet »Repleatur os meum « pa je Samuel Scheidt preoblikoval v obsežen duhovni koncert. ${ }^{11}$ Dokler je Gallus živel, so se pismenim stikom utegnili pridružiti še osebni. Podatek, ki ga je literatura o Gallusu doslej spregledala, pravi, da se je leta 1588 mudil kot gost pri kantoriji v Oschatzu. ${ }^{12}$ Potemtakem ni torej poznal le mesti Breslau in Görlitz v Šleziji, ampak so mu bile najbrž poznane kulturne razmere v osrednji deželi Luthrove reformacije. Vsekakor bi bila koristna naloga, ko bi njegove sledove tu podrobno raziskali. Zdaj naj sledim le tistemu, ki nas vodi v Naumburg, kjer se nahaja obsežen, sijajen rokopis, ki ga je mogoče napisal sam mojster iz Kranjske.

Tam srečamo $v$ mestnih računih njegovo ime dvakrat. Prvič leta 1588, ko beremo )4 Rhein. Goldgulden Jacoben Gallen vor ezliche in roth Leder mit einem guldnen Adler eingebundene Partes, so er dem Rath durch den Schösser zu Eckartsberga anhero geschickt(c. Krajša je kasnejša zabeležba z dne 7. marca 1596 o izplačilu šestih renskih zlatih goldinarjev, ki se glasi: „Jacobi Händeln, sonst Gallus genannt, vor die anher geschickten Partes. (c ${ }^{13}$ Pri tej zabeležbi preseneča, da govori o glasbeniku, ki je že leta 1591 umrl, kot o nekom, ki še živi. Na srečo lahko stvar natančno preučimo, kajti od obsežne in $\mathrm{v}$ marsikaterem oziru edinstvene glasbene biblioteke cerkve sv. Venceslava v Naumburgu je ohranjen le prepis dela skladatelja Antonia Scandellusa, ki je opremljen z razkošnimi barvami. Ta zvezek je bil bržkone najvažnejši del tiste pošiljke, na katero se nanaša zabeležba računa iz leta 1596. Pri tem gre za kodeks v formatu zborske knjige $(43,5 \times 31,6 \mathrm{~cm}) \cdot{ }^{14}$ Rdeči napis, ki je bil poprej napisan na zeleno obarvani platnici iz svinjskega usnja, je obledel. Zdaj lahko prepoznamo le še »ANNO [sledi neka okrasna oblika] 1595 (. Naslov se glasi: )Die Aufferstehung vnsers | lieben herrn vnd heilandes | Jhesu Christi mitt be - | sonderm fleis | Componirt | vonn Antonio Scandello«. Roko-

8 Med drugim velja to za repertoar iz Zörbiga iz približno leta 1600: W. Braun, Zur Musikgeschichte der Stadt Zörbig im 17. Jahrhundert, Archiv für Musikwissenschaft XIII, 1956, str. 274 in dalje.

9 Isti, Der kantor C. Schultze (1606-1683) und die »Neue Musik« in Delitzsch, Wissenschaftliche Zeitschrift Universität Halle-Wittenberg, X/4, 1961, str. 1208 .

10 Isti, Die mitteldeutsche Choralpassion in 18. Jahrhundert, Berlin 1960, str. 188 in dalje.

11 Prim. str. 1212 in dalje $\mathrm{v}$ delu, ki je citirano $\mathrm{v}$ opombi 9; nadalje od istega avtorja: S. Scheidts Bearbeitungen alter Motetten, Archiv für Musikwissenschaft XIX/XX, 1962/63, str. 61.

12 J. Rautenstrauch, Luther und die Pflege der kirchlichen Musik in Sachsen, Leipzig 1907, str. 210.

13 A. Werner, Die alte Musikbibliothek und die Instrumentensammlung an St. Wenzel in Naumburg a.d. Saale, Archiv für Musikwissenschaft VIII, 1926, str. 399.

${ }^{14} \mathrm{~K}$ temu prim. W. Braun, A. Unger und die biblische Historie in Naumburg a. d. Saale, Jahrbuch für Liturgik und Hymnologie VII, 1962, str. 173, 177 in 179. 


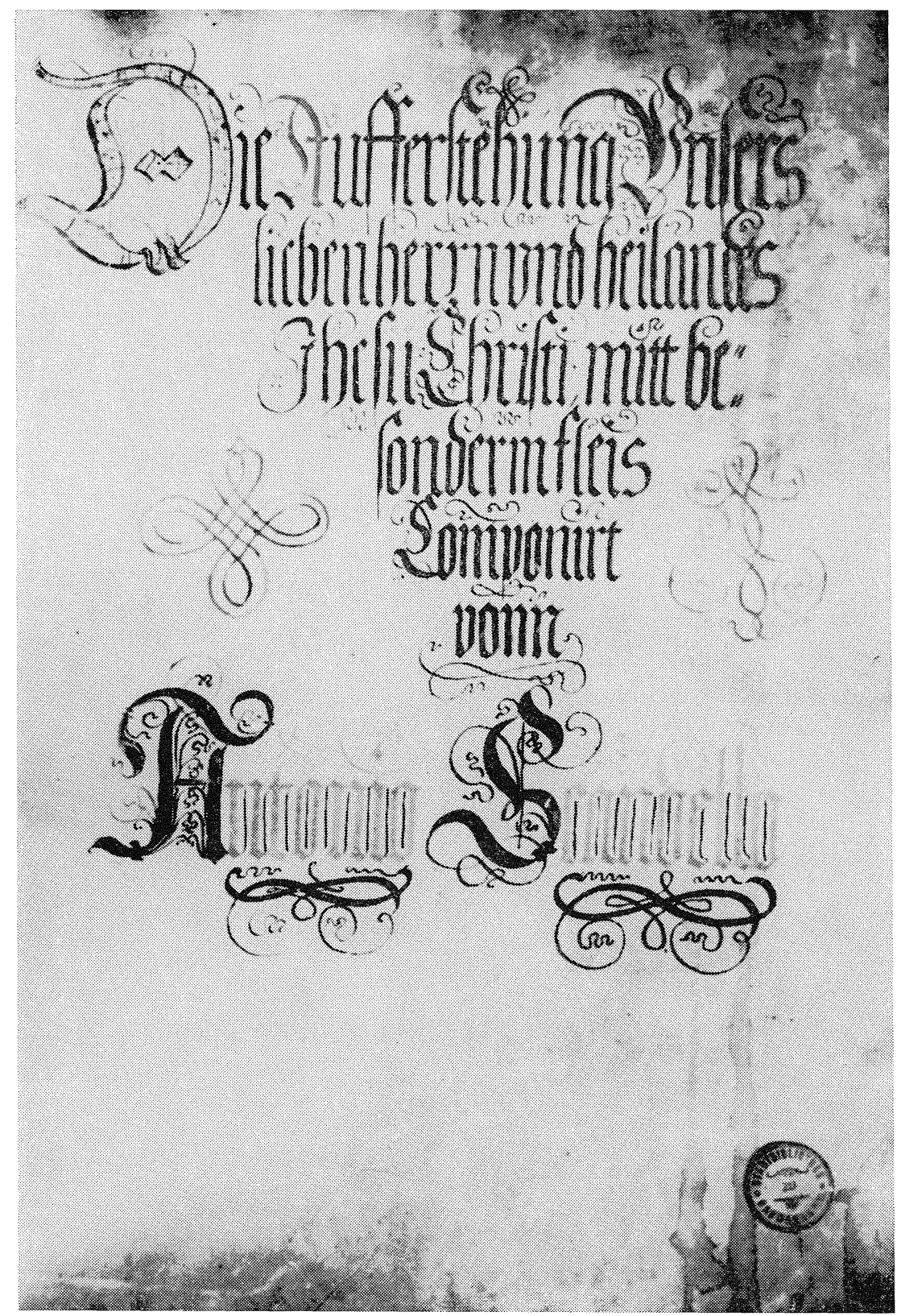

Naslovni list skladbe Die Aufferstehung Vnsers / lieben herrn vnd heilandes / Jhesu Christi Antonia Scandella 
pis obsega 32 listov ( 30 listov po starem štetju $=60$ popisanih strani) in posreduje vse enoglasne in večglasne solistične vloge. Na koncu zvezka pa slede, kot je zabeleženo, „Folgen nuhn die Vers des gantzen Chors, welche vor -zwischen, und nach, dem vorhergehenden Choral und Figural besonders werden gesungen, und darumb in besondere bucher in quarto geschrieben hierbey sind gelegtt, dieselben habe ich auch hierher consignirt I= geschrieben], auf das man sich im Mangel, derselben daraus wiederumb zuerholen haben muge.« Podpisano je z rdečim monogramom, ki ga berem kot »JCH.« in prav tako barvastim križem, ki ima kot podstavek

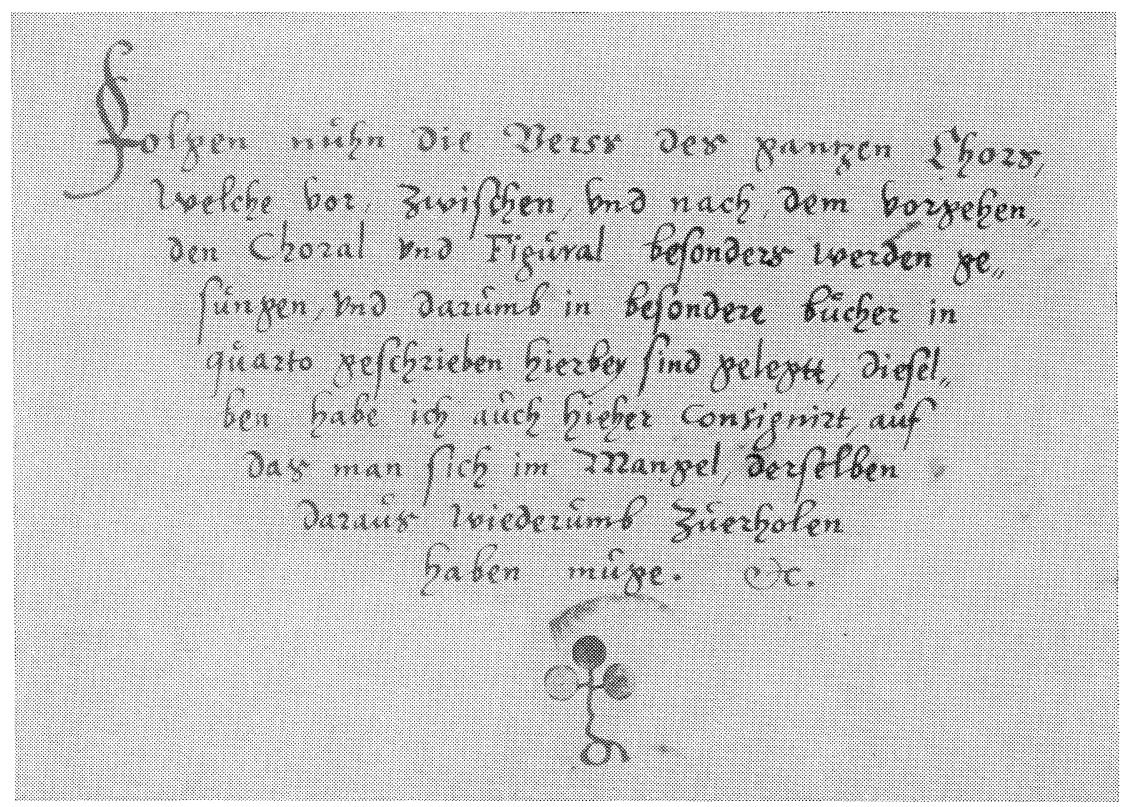

Fragment iz zvezka, ki vsebuje skladbo Die Aufferstehung... Antonia Scandella

črki »g( podobno zanko. ${ }^{14 a}$ Dodani deli so same zborske kompozicije: »Intonatio(, )Primus Versus(, )Secundus Versus( in )Conclusio et Gratiarum actio(c. )Besondere bucher in quarto( danes manjkajo. Vse recitacije evangelista in »Vers des gantzen Chors « kažejo kvadratne oblike not, ki so bile običajne v 16. stoletju. Partije Kristusa imajo napise z zlatimi črkami in so notirane $v$ okroglih, črno obrobljenih notah na rdečih linijah. ${ }^{14 b}$ Kot vodeni znak prepoznamo orla $\mathrm{z}$ dvojno glavo. ${ }^{15}$

14a Podobne okrasne oblike srečujemo večkrat v 16. stoletju, npr. v Kleberjevi rokopisni orgelski tabulaturi (J. Wolf, Musikalische Schrifttafeln für den Unterricht in der Notationskunde, Bückenburg, Leipzig 1922, list 16) ali - kot triperesno deteljico - $\mathrm{v}$ tiskih iz časa reformacije.

14b Slike 1-3: besede in znaki, ki so na fotografiji blede, so $\mathbf{v}$ izvirniku $v$ barvah. Prim. opis rokopisa. Posnetki: Zentralarchiv Merseburg in privatno.

15 Ne pri Briquetu. Prim. tudi zgoraj navedeni opis Knjig glasov iz leta 1588. 


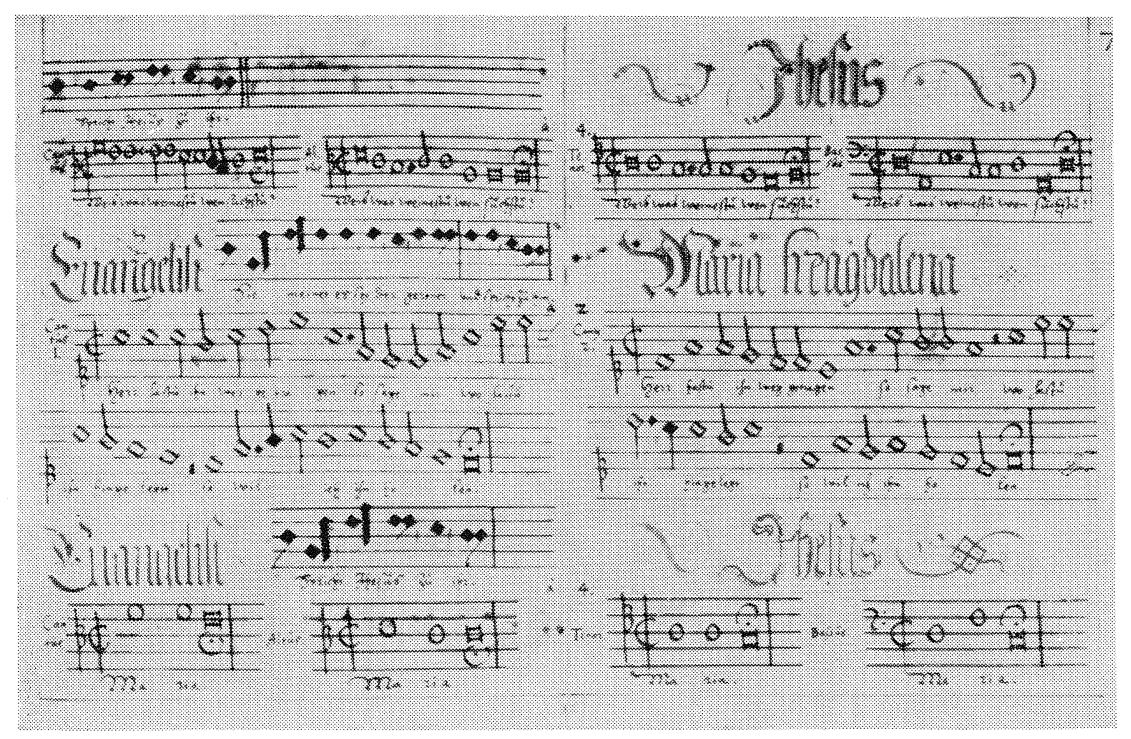

Fragmenti iz skladbe Die Aufferstehung... Antonia Scandella

Istovetenje pošiljke, ki jo omenja zabeležba računa iz leta $1596, \mathrm{~s}$ tem rokopisom se opira seveda najprej na monogram $) \mathrm{JHC}_{(}$, ki ga lahko razrešimo kot »Jakob Handl Carniolus« in ki je verjetno dopolnjen $\mathrm{s}$ ) $\mathrm{G}(=)$ Gallus« $\mathrm{v}$ spodnjem delu križa. Razen tega na dejstvo, da se zabeležba $\mathrm{z}$ dne 7. marca 1595 dobro ujema $\mathrm{z}$ velikonočno kompozicijo z letnico 1595. S tem bi si lahko razložili tudi nenavadno nespretno formulacijo komentarja, saj po splošnem naziranju nemščina ni bila materin jezik )Carniolusa(. Kako pa je potem odstraniti protislovje med temi ugotovitvami in biografijo skladatelja? Očitno imamo opraviti s spretno manipulacijo skladateljevega brata in dediča Jurija Gallusa. ${ }^{16}$ Jurija, ki je bil tiskar v Pragi, je kot upravitelja zapuščine znamenite osebnosti vodila želja, da bi dal tiskati še nenatisnjene Jakobove kompozicije, in jih s tem napraviti splošno dostopne. Razen tega si je obetal od tega in od prodaje drugih muzikalij, ki so pripadale njemu, finančni dobiček. Leta 1596 je posvetil »Moralia(c kot zadnji del posvetnih kompozicij svojega brata senatu mesta Prage. )Zgodbo o vstajenju (c je napravil aktualno z dodatkom letnice $) 1595$ ( ali pa s korekturo nekega starejšega datuma na ovitku in jo tako poslal z napačnim ali manjkajočim imenom svetu mesta, kamor, kot je domneval, vest o smrti njegovega brata še ni dospela. Kot »Jakob Handl Carniolus« si je nadejal večjih nasprotnih uslug kot pa »Georg Handl Carniolus«. Tiskar se res ni varal. Prejel je za tedanje razmere nikakor neznatno vsoto šestih renskih zlatih goldinarjev, medtem ko je

16 Nepopoln ponatis inventarja iz leta 1591 pri J. Mantuaniju, DTÖ VI, 1, str. XXXII in dalje. 
dobil osem let poprej davkar iz Eckartsberga, ki je posredoval za skladatelja, za rdeče parte (gotovo dele zbirke »Opus musicum(, ki je omenjena v naumburškem inventarju iz leta 1636) le štiri renske zlate goldinarje.

Če so ta razmišljanja pravilna, bi bil pobliže opredeljen eden od najbolj impresivnih srednjenemških glasbenih rokopisov iz zadnje tretjine 16. stoletja, ki je vplival na glasbo Naumburga vse $v$ 18. stoletje $^{17}{ }^{17}$ raziskovanje Gallusa pa bi bilo tudi obogateno z dragocenim dokumentom. Znova bi postalo jasno, kako sta si bili še tedaj blizu umetnost lepega pisanja in umetnost skladanja. Kot kažejo priložene slike, izvirajo vsaj notam podloženi teksti, oznake glasov in komentar z monogramom »JHC، oziroma » $\mathbf{G}_{\text {( }} \mathrm{iz}$ iste roke. Verjetno pa tudi note, naslov in napisi $\mathrm{k}$ osebam, ki pojejo. Ker zasluži letnica, ki je vpisana na ovitek, nezaupanje, in ker se vodnega znaka uporabljenega papirja doslej ni dalo z gotovostjo datirati, ostane čas nastanka kodeksa neznan. Vendar mu kot domnevnem autografu enega od najpomembnejših glasbenikov pred letom 1591 pripada velik pomen vira. Dejansko sledi še stari razporeditvi teksta Johanna Bugenhagena, ${ }^{18} \mathrm{ki}$ pa je bila spremenjena $\mathrm{v}$ tiskih 17 . stoletja. Ni izključeno, da je dobil predlogo Gallus neposredno od dresdenskega kapelnika Antonia Scandella (1517-1580). Ker je bil zvezek prodan šele po smrti osebe, ki ga je izdelala, se vsiljuje domneva, da je bila nemška »Zgodba o vstajenju « tega italijanskega konvertita, ki je nastala za protestantsko bogoslužje v saški prestolnici, izvedena v cerkvi cesarske Prage, kjer je služboval katoliški kantor in kranjski mojster Jakob Handl (Gallus) —, res )internacionalna« perspektiva.

\section{SUMMARY}

Almost the only work from the large library of the church of St. Wenceslas in Naumburg still extant is a copy of the Auferstehungshistorie of Antonio Scandello. The manuscript, dated 1595, contains both monophonic and polyphonic solo roles; at the end the verses of the entire chorus are also added. This manuscript is signed with a red monogram consisting of the letters J.H. C. and a cross, with a loop at the foot of the shape of a letter G. This monogram could be explained as denoting Jacob Handl Carniolus and as Gallus. This assumption is corroborated by an entry in an accounts book where we find in connection with the payment of 6 golden Rhenish gilders on the date 7th March 1596 the following comment: :Jacobi Händeln, sonst Gallus genannt, vor die anher geschickten Partes«. Apparently the manuscript of the church of St. Wenceslas is identical with the compositions of the consignment referred to in the accounts book. As Jacob Gallus was already dead in 1591 his brother George sent the manuscript of the Auferstehungshistorie, which was among the belongings of the composer, to the town council of Naumburg. Hoping to obtain more money for it he sent it under the name of his famous brother. The commentary in the Auferstehungshistorie is written in an awkward language, which is completely in accordance with the general opinion

17 Prim. op. 14.

18 Str. 189 v delu, navedenem v opombi 10. 
that German was not the mother tongue of Gallus. As can be seen from the photographs accompanying this paper, the texts under the music, the annotation of the voices, and the commentary, with the monogram J.H. C. and G. come from the same hand. Probably also the musical notation, the title and the inscriptions for individual singing characters have the same origin. It seems we have a precious document to deal with which might mean an enrichment of the field of Gallus research. 